\title{
Morphological and Physiological Responses of Cedrela Fissilis Vellozo (Meliaceae) Seedlings to Light
}

\author{
Débora Leonardo dos $\operatorname{Santos}^{1}$, Miroslava Rakocevic ${ }^{2}$, Massanori Takaki ${ }^{3 *}$ and Jorge \\ Ribaski $^{2}$ \\ ${ }^{1}$ Universidade Estadual do Sudoeste da Bahia; Estrada do Bem-Querer km 04; 45083-900; Vitoria da Conquista - \\ BA - Brasil. ${ }^{2}$ EMBRAPA Florestas; Estrada da Ribeira km 111; C. P. 319; 83411-000; Colombo - PR - Brasil . \\ ${ }^{3}$ Universidade Estadual Paulista; Departamento de Botânica; C. P. 199; 13506-900; Rio Claro - SP - Brasil
}

\begin{abstract}
Seeds of Cedrela fissilis Vellozo were planted and maintained under two distinct conditions: at east border of a forest with red: far-red ratio of 1.15 and under canopy with photosynthetic photon flux density of $0.22-7 \%$ of full sun radiation and red: far-red ratio of 0.21-0.36. Seedling growth (height and stem diameter) was faster under sun, the development of roots more continuous and the number of leaves almost twice of that of shade plants. The leaf area was 10 times greater in sun plants with 15-25 leaflets per leaf while under shade only 5 to 10 leaflets were found per leaf. In shade plants, a higher proportion of dry mass was found in aerial parts. Leaves of sun plants had the capacity of gas exchange to respond to high light radiation, but leaves adapted to shade presented a lower response to light changes. When shade plants were transferred and maintained under the sun for 15 days, only the young leaves were adapted to increased light radiation, reaching the same photosynthetic rate as sun plants, while old leaves were shed. Sun plants transferred to shade conditions did not lose leaves, but did not reach the same photosynthetic rate attained by shade plants.
\end{abstract}

Key words: Photosynthesis, seedling morphogenesis, shade

\section{INTRODUCTION}

The knowledge of physiological processes for tropical forest species, especially responses to light, is important for preservation of plants with economical potential. It is also important in the production of young plants for reforestation projects. Natural gaps are important for the internal regeneration of tropical forests (VázquezYanes and Smith, 1982). Differences in light quality and quantity under forest gaps and canopies have direct effects on seed germination, seedling growth and establishment (Marquis et al., 1994).
The phytochrome is responsible for the perception of light environment (Smith, 1994). This photoreceptor detects a shade inducing changes in the metabolism and development (Casal and Sánchez, 1998). The red:far-red ratio (R:FR) is reduced under dense canopy when compared to open areas. Due to this reduction plants detect shade and reflection produced by neighbouring plants (Ballaré and Casal, 2000). The first photomorphological response to shade (low R:FR) is the shoot elongation (Smith, 1994) which is in several cases, accompanied by reduction in ramification and number of leaves (Rakocevic,

* Author for correspondence 
1997) and increase in the individual leaf size and petiole length (Gautier et al., 2000).

Phenotypic plasticity can be defined as the capacity of a genotype to produce different phenotypes adapted to different environments (Aphalo et al., 1999). The classic example of phenotypic plasticity is the dichotomy between sun and shade leaves. This difference can be expressed not only in plants of the same species growing in different light environment, but also inside the canopy of the same plant, depending on the position of the leaf. Leaves positioned at the low portion of the canopy respond to reduced photosynthetic photon flux density (PPFD) and R:FR ratio, which affects directly their development (Richardson et al., 2001).

The leaf carbon assimilation depends on distinct environmental, physiological and morphological characteristics, as is the leaf ability to intercept light, determined by leaf area, geometry (petiole inclination and leaf angle), structure, characteristics related to light (absorption, transmittance and reflection) and plant developmental stage. Considering light environment, the $\mathrm{CO} 2$ assimilation is influenced by changes in PPFD, but not by R:FR ratio (Heraut-Bron et al., 2001) in majority of species.

The R:FR ratio improves the light interception area by modifying leaf morphology. The photosynthetic properties of leaves change with the PPFD incident on leaf surface (Givnish, 1988), widely studied linkage (Kull and Kruijt, 1998). The morphological acclimation of leaves regulates the light interception by individual leaf of a single plant. The PPFD at the level of shade leaf can be up to 20 times lower than the level at the sun leaf, and the morphological plasticity of branches can reduce those differences to light interception up to 12 times (Planchais and Sinoquet, 1983).

Cedrela fissilis Vellozo (Meliaceae), known as "cedro rosa" in Brazil, is an early secondary species or a late secondary species. It develops well inside a primary tropical forest and has high aggressiveness in secondary forests. It is widely distributed in all tropical vegetation, except in the Cerrado. The tree shed leaves in dry and cold season, and grows to 10 to 25 meters in height. The wood is light, soft and easy to be worked. It is an important species in the reforestation programs (Carvalho, 1994). Young C. fissilis plants are found frequently in the border of forest and gaps, which allows the seedlings to receive direct sun light. The purpose of the present work was to determine the morphological and physiological responses of $C$. fissilis seedlings to shade and full sun and acclimation of leaves to simulated conditions of radiation under opening and closure of gaps of the canopy, by analysis of photosynthetic rates of leaves, and by growth analysis.

\section{MATERIAL AND METHODS}

Seeds of C. fissilis were collected from trees grown in Itirapina, São Paulo $\left(22^{\circ} 15^{\prime} \mathrm{S}, 47^{\circ} 42^{\prime}\right.$ W). Five seeds each were planted in 180 plastic pots (5l) containing a mixture of clay and humus (2:1). Ninety vessels were maintained at the east border of the forest (sun treatment) and 90 vessels under canopy (shade treatment), in the dense forest uniform park site at UNESP Campus $\left(22^{\circ} 23^{\prime} \mathrm{S}\right.$, $47^{\circ} 42^{\prime}$ W). Emerged seedlings were counted daily to calculate germination percentage and germination rate. After one month, seeds were sown in all treatments the seedlings were trimmed and only one seedling was maintained in each vessel. The vessels were watered daily. The morphological parameters analysed every 15 days during six months were: seedling height, stem diameter at soil level and number of leaves. Every two months, ten seedlings were collected from each treatment for destructive analysis of leaf area with the aid of a CI-202 Area Meter (QC CID Inc.), fresh and dry weight of roots, leaves and stems and root length. The growth parameters analysed were: relative growth rate (RGR) calculated according to Leopold and Kriedemann (1978), $\mathrm{RGR}=\left(\operatorname{lnW}_{2}-\operatorname{lnW}_{1}\right):\left(\mathrm{t}_{2}-\mathrm{t}_{1}\right)$; leaf area ratio (LAR) LAR=leaf area:dry mass, according to Wareing and Phillips (1970), absolute growth rate (AGR), $\quad \mathrm{AGR}=(\mathrm{Pt}-\mathrm{P} 0)$; net assimilatory rate $(\mathrm{NAR}), \quad \mathrm{NAR}=\left[\left(\mathrm{W}_{2}-\mathrm{W}_{1}\right):\left(\mathrm{t}_{2}-\mathrm{t}_{1}\right)\right] \cdot\left[\left(\ln \mathrm{A}_{2}-\ln \mathrm{A}_{1}\right):\left(\mathrm{A}_{2}-\right.\right.$ 1)] according to Hunt (1982); root aerial part ratio (RAP), RAP=root dry mass:aerial part dry mass; root mass ratio (RMR), RMR=root dry mass:total dry mass; stem mass ratio (SMR), SMR=stem dry mass:total dry mass; leaf mass ratio (LMR), LMR=leaf dry mass:total dry mass; leaf mass per area unit (LMA), LMA=leaf dry mass:leaf area according to Walters and Reich (1996).

Net photosynthesis $(\mathrm{Pn})$ of 10 seedlings was measured using a LI-6200 (LI-COR, USA) photosynthesis system, with four readings for each leaflet, each of 5 seconds duration. The R:FR ratio was determined by LI-1800 (LI-COR, USA) 
spectroradiometer. During the determination of photosynthesis rate, PPFD and the temperature at leaf level were measured with the LI-6200.

The potential of adaptation to different conditions of light at the level of the same leaf was analysed by measuring photosynthesis in ten sun and shade plants in three settings: 1/ natural environment during the morning and afternoon, $2 /$ in a glass house with neutral shade for determination of photosynthesis rate at limited conditions and $3 /$ at noon, on the open area, at unlimited conditions of light.

The potential of adaptation to disturbed conditions at simulated gap opening and gap closure were determined by maintaining ten sun plants under canopy shade and ten shade plants in sun conditions. After 15 days, the photosynthesis rate, PPFD at leaf level and morphological parameters were determined. Leaf chlorophyll content was determined in five $11 \mathrm{~cm}$ diameter leaf discs extracted with $80 \%$ acetone with $\mathrm{CaCO}_{3}$ (Arnon, 1949). After centrifugation (2000xg, 5 minutes) the final volume of supernatant adjusted to $20 \mathrm{ml}$ and the $\mathrm{A}_{645} \mathrm{~nm}$ and $\mathrm{A}_{663} \mathrm{~nm}$ were determined in a FEMTO spectrophotometer (Brazil) for determination of chlorophyll a, b and total contents. The results were analysed by StudentNewman-Keuls One Way ANOVA tests.

\section{RESULTS}

All seeds started to emerge fifteen days from sowing and no difference was observed either in percentage germination or in germination rate between sun and shade plants. Growth of plants maintained at the forest border, was faster than others maintained under shade (Fig. 1). This slow growth was probably caused by diminished PPFD and spectral alteration. In sun treatment PPFD and $\mathrm{R}: F R$ ratio were $23.9-649.7 \mu \mathrm{mol} . \mathrm{m}^{-2} . \mathrm{s}^{-1}$ and $1.15-$ 1.27 , respectively. Under canopy the PPFD attained $1.8-2.24 \mu \mathrm{mol} . \mathrm{m}^{-2} \cdot \mathrm{s}^{-1}$ and R:FR ratio of 0.21-0.36 (Table 1).

Thirty day-old seedlings presented a lower stem height under sun than in the shade, due to etiolation of shade plants (Fig. 1A). Later, stem elongation of sun plants was very fast, and after 90 days, the height attained was statistically different from that of shade plants. The difference in elongation rate was maintained until the end of the experiment (Fig. 1A). Stem diameter of sun plants was statistically greater, even after 30 days (Fig. 1B) attaining a diameter of 1.8 to $16 \mathrm{~mm}$ after 225 days, compared to shade plants (average 1 to $3.5 \mathrm{~mm}$ ). The number of leaves of sun plants was, on average, twice of shade plants (Fig. 1C), while the leaf area was ten times greater.

Dry mass of hypocotyls was lower in shade-grown plants (Table 2). Generally, the biomass produced by shade plants was lower.

The shade plants started root development between 60 to 90 days of experiment (Fig. 1D) while under full sun increase in root length was constant until the end of experiment.

Table 1 - Average values of PPFD $\left(\mu \mathrm{mol} . \mathrm{m}^{-2} . \mathrm{s}^{-1}\right)$ and R:FR ratio in environment where photosynthesis has been measured.

\begin{tabular}{|c|c|c|c|c|c|c|c|}
\hline & \multicolumn{2}{|c|}{ Sun } & \multicolumn{3}{|c|}{ Shade } & \multicolumn{2}{|c|}{ Greenhouse } \\
\hline & PPFD & R: FR & PPFD & \multicolumn{2}{|c|}{ R: FR } & PPFD & R: FR \\
\hline Morning & 395.6 & 1.25 & 2.24 & \multicolumn{2}{|c|}{0.21} & & \\
\hline Midday & 649.7 & 1.27 & 1.41 & \multicolumn{2}{|c|}{0.14} & 116.0 & 1.32 \\
\hline Afternoon & 23.9 & 1.15 & 1.8 & \multicolumn{2}{|c|}{0.36} & & \\
\hline $\begin{array}{l}\text { Natural condi } \\
\text { with sun and }\end{array}$ & ly average, day & PPFD & \pm s.e. & $\operatorname{Air}\left({ }^{\circ} \mathrm{C}\right)$ & \pm s.e. & Leaf $\left({ }^{\circ} \mathrm{C}\right)$ & \pm s.e. \\
\hline Sun plants & & 621.70 & 116.43 & 31.07 & 0.34 & 31.91 & 0.55 \\
\hline Shade plants & & 9.21 & 2.35 & 29.04 & 0.15 & 28.92 & 0.15 \\
\hline \multicolumn{8}{|l|}{ Greenhouse } \\
\hline Sun plants & & 174.11 & 8.61 & 24.20 & 0.15 & 24.00 & 0.17 \\
\hline Shade plants & & 177.68 & 8.31 & 25.91 & 0.09 & 25.67 & 0.10 \\
\hline \multicolumn{8}{|c|}{ Midday, a day with sun and clouds } \\
\hline Sun plants & & 941.05 & 41.79 & 27.77 & 0.13 & 28.71 & 0.17 \\
\hline Shade plants & & 890.71 & 32.45 & 28.76 & 0.21 & 29.64 & 0.29 \\
\hline
\end{tabular}


A

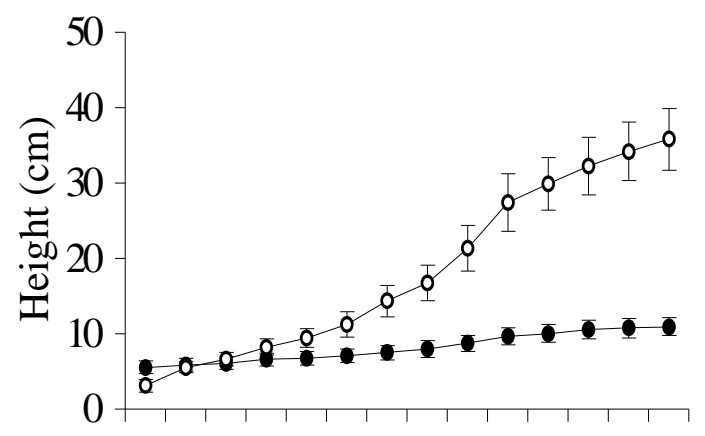

$\begin{array}{lllllll}30 & 60 & 90 & 120 & 150 & 180 & 210\end{array}$

Age (days)

C

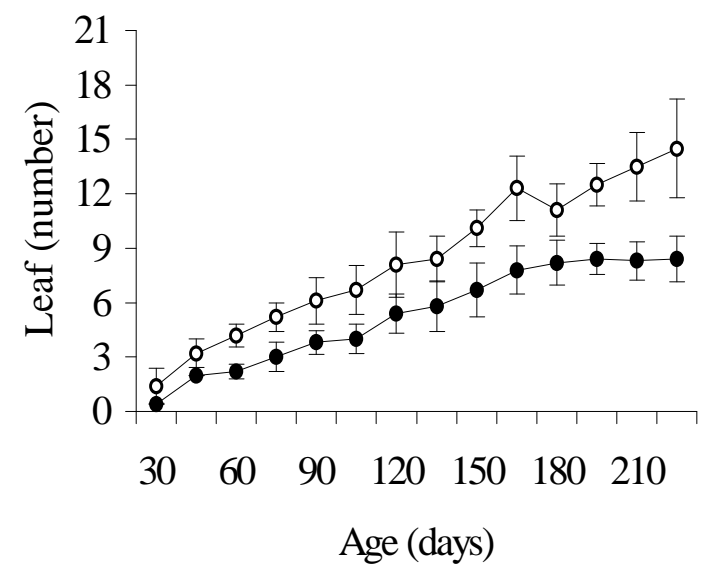

B

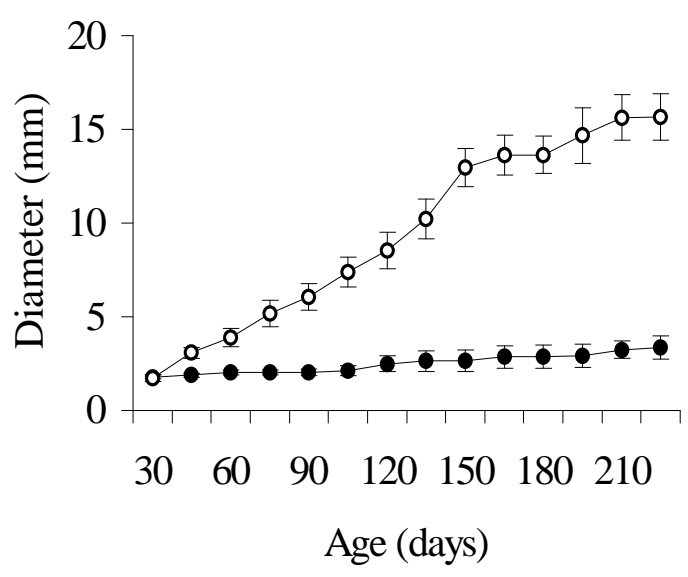

D

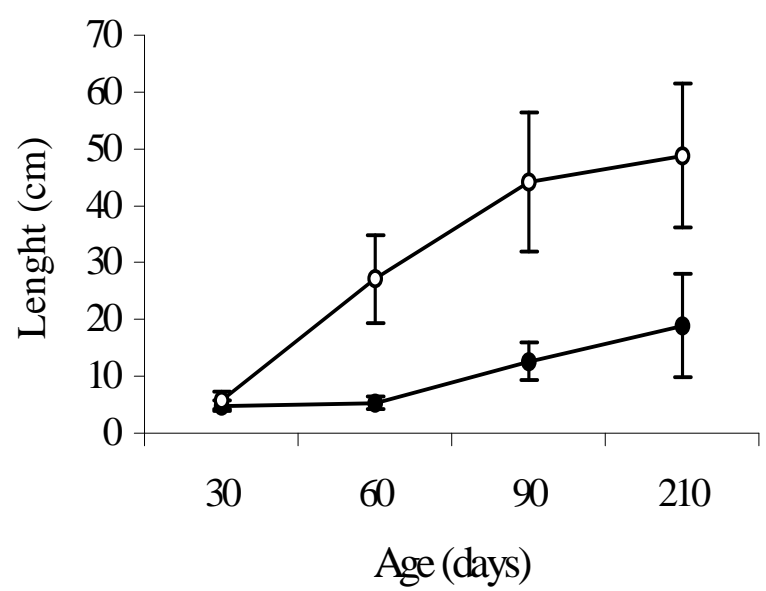

Figure 1 - Values of growth averages for young plants of Cedrela fissilis maintained for 225 days in a shade and under sun: A) height; B) stem diameter on soil height; C) number of leaves and D) root length. The vertical bars indicate \pm standard error of mean. $\left(-^{\circ}-\right)$ sun plants and $(-\bullet-)$ shade plants.

Table 2 - Dry mass per compartments: cotyledon, leaf, root and stem of Cedrela fissilis. The small letters indicate the comparison between averages in sun and shade treatments, and capital letters between light treatments and age.

\begin{tabular}{|c|c|c|c|c|c|c|c|c|}
\hline \multirow{3}{*}{$\begin{array}{c}\text { Age } \\
\text { (days) }\end{array}$} & \multicolumn{8}{|c|}{ Dry mass (mg) } \\
\hline & \multicolumn{2}{|c|}{ cotyledon } & \multicolumn{2}{|c|}{ leaf } & \multicolumn{2}{|c|}{ stem } & \multicolumn{2}{|c|}{ root } \\
\hline & shade & sun & shade & sun & shade & sun & shade & sun \\
\hline 30 & $15.6 \mathrm{aA}$ & $19.8 \mathrm{aB}$ & $1.3 \mathrm{cE}$ & $6.0 \mathrm{dE}$ & $7.0 \mathrm{cE}$ & $10.2 \mathrm{dD}$ & $3.7 \mathrm{dF}$ & $6.8 \mathrm{dE}$ \\
\hline 90 & $21.9 \mathrm{aA}$ & $15.5 \mathrm{bA}$ & $26.5 \mathrm{bD}$ & $454.6 \mathrm{cC}$ & $12.9 \mathrm{bD}$ & $153.4 \mathrm{cC}$ & $7.1 \mathrm{cE}$ & $202.0 \mathrm{cC}$ \\
\hline 150 & $8.4 \mathrm{bC}$ & - & $358.7 \mathrm{aC}$ & $5008.6 \mathrm{bB}$ & $89.9 \mathrm{aC}$ & $1838.3 \mathrm{bB}$ & $71.8 \mathrm{bD}$ & $2691.8 \mathrm{bB}$ \\
\hline 210 & - & - & $626.9 \mathrm{aC}$ & $12499.4 \mathrm{aA}$ & $228.8 \mathrm{aC}$ & $8118.2 \mathrm{aA}$ & $198.3 \mathrm{aC}$ & $8118.2 \mathrm{aA}$ \\
\hline
\end{tabular}


RGR decreased in sun plants against time. In shade plants, RGR increased between $90^{\text {th }}$ and $150^{\text {th }}$ day, and decreased between $150^{\text {th }}$ and $225^{\text {th }}$ day (Fig. 2A). The increase of RGR in shade plants for the period between $90^{\text {th }}$ and $150^{\text {th }}$ day, could be explained by the presence of cotyledons.

NAR was constant for sun and shade plants although lower under shade than under full sun (Fig. 2C). After 150 days showed practically no

$\mathbf{A}$

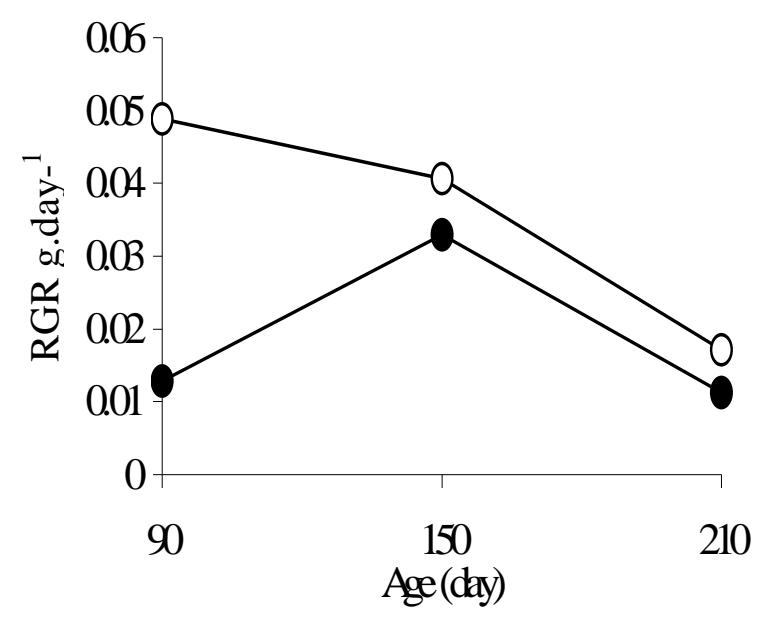

modification (Fig. 2B and Table 2). NAR, which represented the net efficiency of plants in dry mass production, was greater in sun plants, related to increase of leaf mass (Fig. 2C). NAR as the physiological leaf performance parameter, showed no significant oscillation in time for both sun and shade plants.

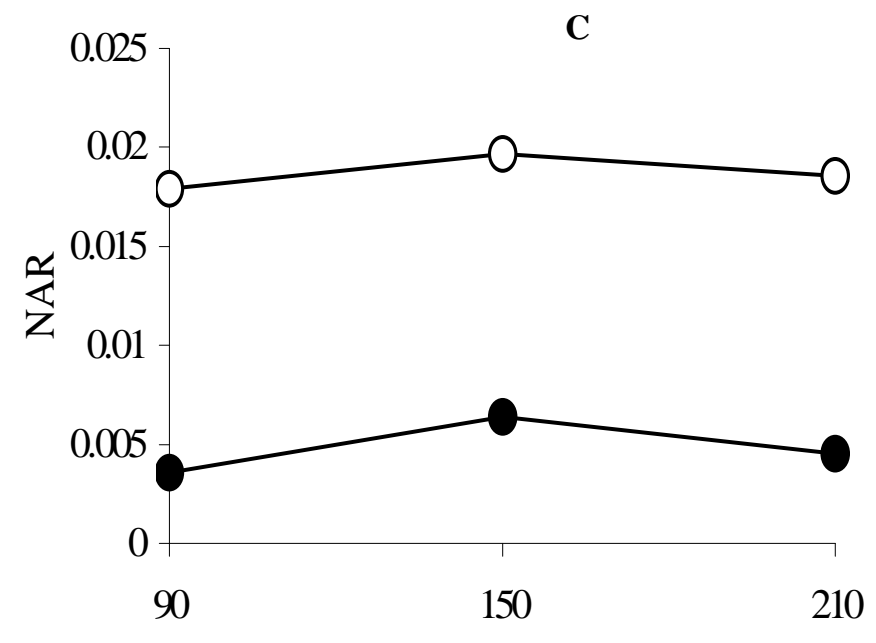

Age (day)

Figure 2 - Growth rates in relation to dry mass of Cedrela fissilis young plants maintained under sun $\left(-^{\circ}-\right)$ and under shade of canopy (-๑-). A) Relative growth rate (RGR), B) Absolute growth rate (AGR) and C) Net assimilation rate (NAR). The small letters indicate the comparison between averages in "sun" and "shade" treatments, and capital letters indicates comparison between treatments. 


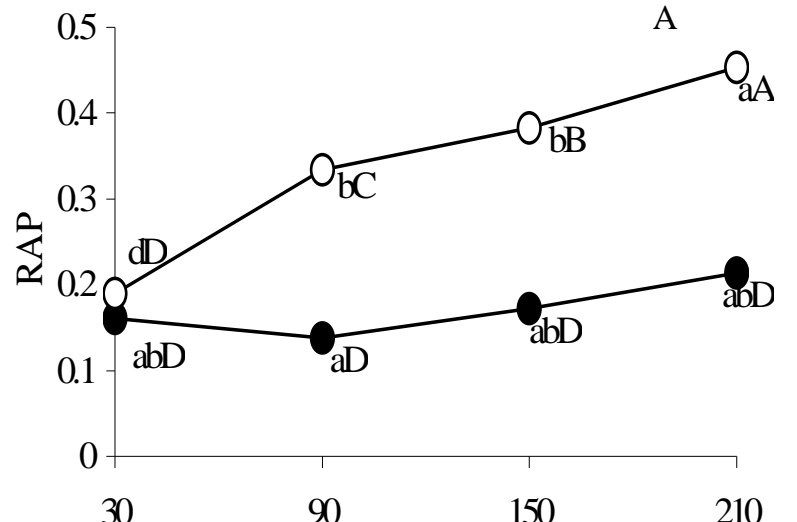

Age (day)
B

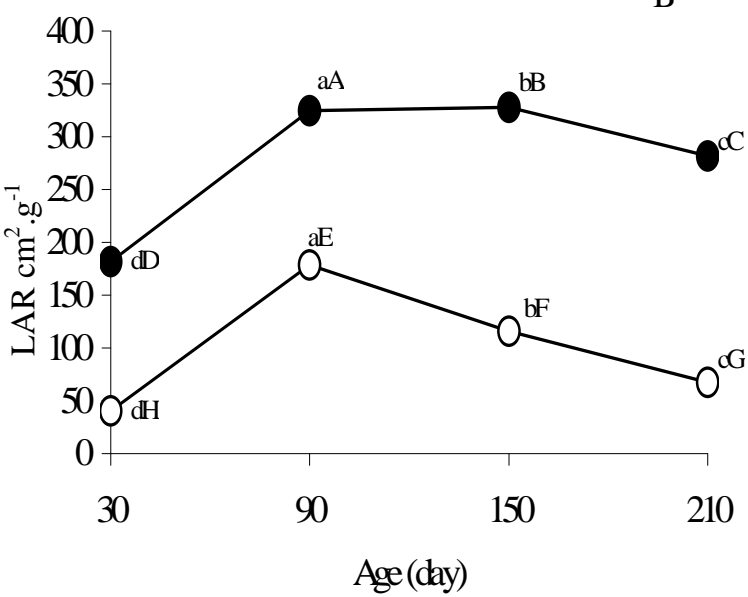

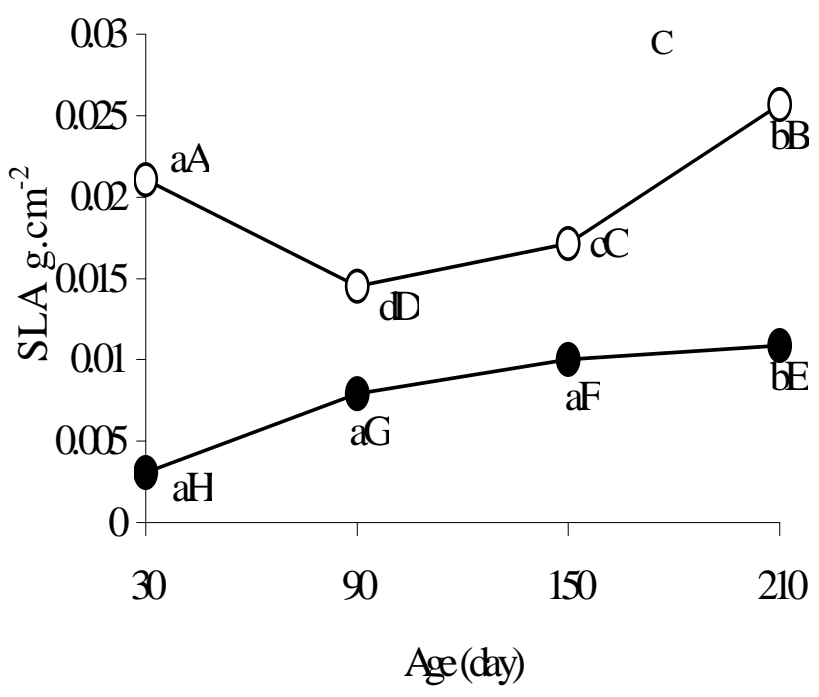

Figure 3 - Growth rates in relation to dry mass of Cedrela fissilis young plants maintained under sun $\left(-^{\circ}-\right)$ and under shade of canopy (-•-). A) Root:aerial part ratio (RAP); B) Ratio of leaf area (LAR) and C) Specific leaf area (SLA). The small letters indicate the comparison between averages in "sun" and "shade" treatments, and capital letters indicates comparison between treatments.

Sun plants AGR increased during the growing period, while shade plants AGR was almost low and constant (Fig. 2B). The shade plants had a low RAP (Fig. 3A), indicating that those plants allocated relatively more of biomass to aerial part than to roots. Also, they developed thin leaves with low SLA (Fig. 3C), with high LAR (Fig. 3B) and invested greater portion of total dry mass in leaf dry mass compared to plants grown in the forest border. Analysis of biomass allocation showed that after the 90-day period a higher portion of carbon was invested into leaves, mainly in shade plants (Table 3).
Shade plants developed physiological adaptations (Figs. 4A and 4B) for maintenance of plant structure. Under natural conditions (Table 1) leaves of shade plants showed the net photosynthetic rate $(\mathrm{Pn}) 0-5 \mu \mathrm{molCO} 2 \cdot \mathrm{m}^{-2} \cdot \mathrm{s}^{-1}$ (Fig. 4A) on $2.5-52 \mu \mathrm{mol} . \mathrm{m}^{-2} \cdot \mathrm{s}^{-1}$ PPFD (Table 1, PPFD value of $9.21 \mu \mathrm{mol} . \mathrm{m}^{-2} \cdot \mathrm{s}^{-1}$ was measured at leaf level). Response comparison of the same leaves of shade plants exposed to sun radiation inside greenhouse and under midday sun, showed a restricted gas exchange (Fig. 4A). On the other hand, leaves of sun plants had the ability to respond to high light radiation, attaining a Pn of 
$18.5 \mu \mathrm{molCO} 2 \cdot \mathrm{m}^{-2} \cdot \mathrm{s}^{-1} \quad$ (average value was $11.35 \mu \mathrm{molCO}_{2} \cdot \mathrm{m}^{-2} \cdot \mathrm{s}^{-1}$, Fig. $4 \mathrm{~A}$ ).

In shade plants, only the young leaves showed adaptation to increased radiation; the others became senescent during the 15-day period of changed light environment. Therefore, young leaves rapidly reached the full capacity of plants to grow in forest border (Fig. 4C). On the other hand, sun plants transferred to canopy shade did not lose their leaves so rapidly. But they also became yellowish and the photosynthetic response was five times lower than that of plants maintained under full sun. They even did not attain the response of shade plants, showing a significant $40 \%$ reduction in Pn when compared to shade plants (Fig. 4C). Chlorophyll (Chl) a and b content and $\mathrm{Chl} a: b$ ratio, calculated on a leaf area basis, were not statistically different, although they showed a tendency to be higher in sun plants than in shade plants (Fig. 4D).

Leaf area increased constantly ten times more in sun plants until $210^{\text {th }}$ day (Fig. 4 C). When at $210^{\text {th }}$ day plants alternated light environment, the $\mathrm{AF}$ reduction occurred at $210^{\text {th }}-225^{\text {th }}$-day period.
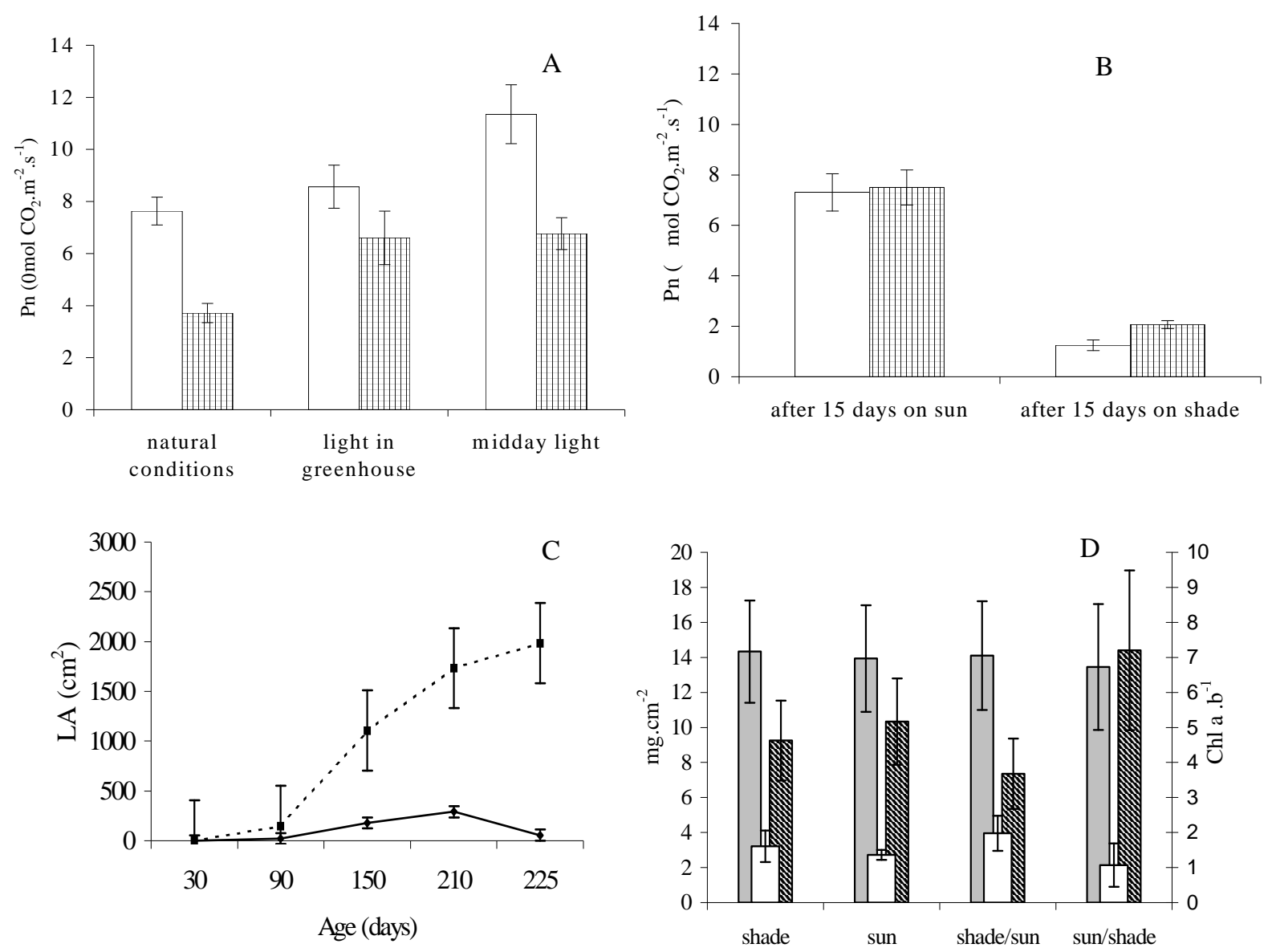

Figure 4 - Morphological, biochemical and physiological relationships in young plants of Cedrela fissilis. A) Net photosynthesis rate (Pn) of plants of experiment 1 - modifications of daily climate; B) Net photosynthesis rate (Pn) of plants of experiment 2 - 15 days after the modification of light conditions C) Leaf area (--- sun plants and - shade plants) D) Chlorophyll (Chl) content of plants with 15 days after the modification of light conditions. The vertical bars indicate \pm standard error of mean. $\square$ - Sun plant and $\boxplus$ - Shade plant. $\square$ Chl a, $\mathbb{N}$ Chl b and $\square \mathrm{Chl} \mathrm{a:b.}$ 


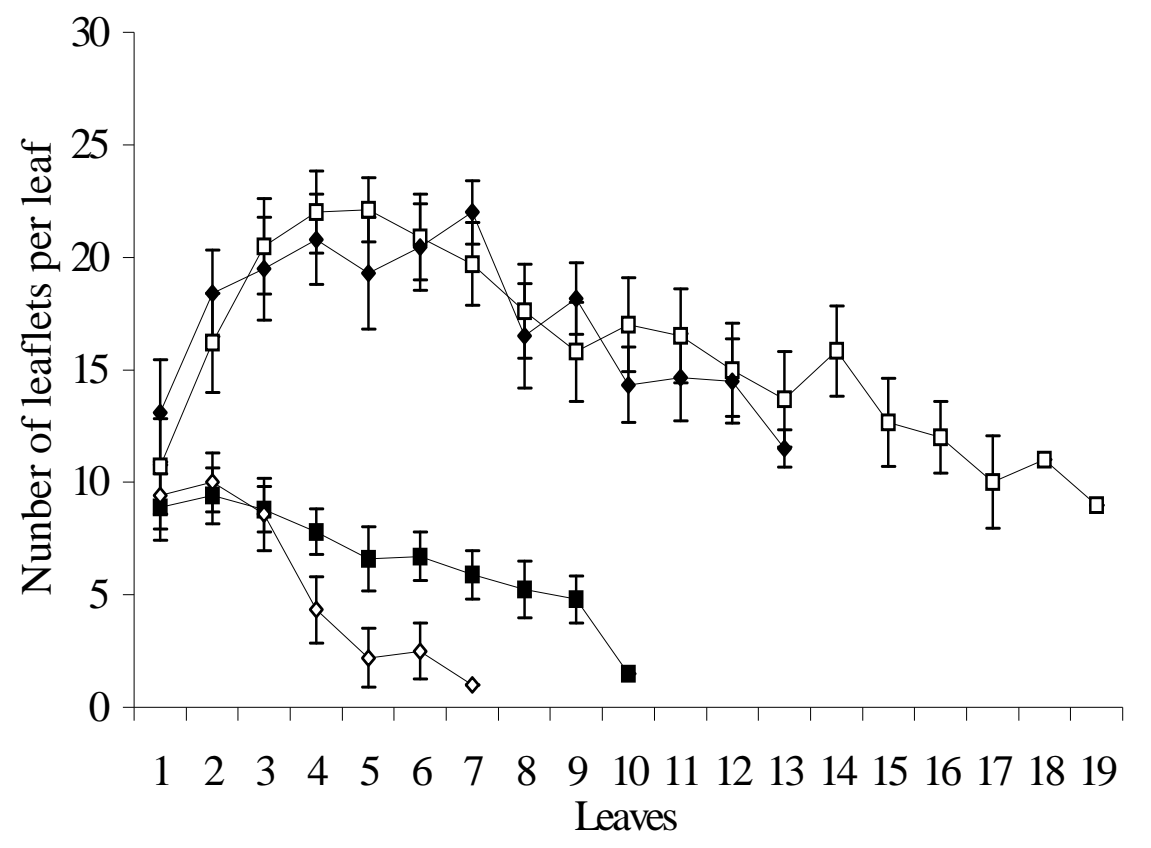

Figure 5 - Number of leaflet per leaf of young plants of Cedrela fissilis. The leaves are represented by the sequence opposite on appearance on stems (leaf 1 is the youngest). The vertical bars indicate \pm standard error of mean. - $\square$ - sun and - $\square$ - shade plants; $->$ - shade plants maintained for 15 days under full sun and - sun plants maintained for 15 days under shade.

Table 3 - Stem mass ratio (SMR), root mass ratio (RMR) and leaf mass ratio (LMR), calculated in relation on dry mass every 60 days. The small letters indicate the comparison between averages in sun and shade treatments, and capital letters between light treatments and age.

\begin{tabular}{ccccccc}
\hline $\begin{array}{c}\text { Age } \\
\text { (days) }\end{array}$ & \multicolumn{2}{c}{ SMR $\left(\mathbf{g . g}^{-1}\right)$} & \multicolumn{2}{c}{ RMR $\left(\mathbf{g . ~}^{-\mathbf{1}}\right)$} & \multicolumn{2}{c}{ LMR $\left(\mathbf{g . g}^{-1}\right)$} \\
Shade & sun & shade & sun & shade & sun \\
\hline 30 & $0.26 \mathrm{aA}$ & $0.24 \mathrm{aB}$ & $0.14 \mathrm{aD}$ & $0.16 \mathrm{cD}$ & $0.05 \mathrm{dH}$ & $0.14 \mathrm{dG}$ \\
90 & $0.23 \mathrm{bB}$ & $0.16 \mathrm{aBC}$ & $0.12 \mathrm{aD}$ & $0.24 \mathrm{bC}$ & $0.40 \mathrm{cF}$ & $0.55 \mathrm{aC}$ \\
150 & $0.14 \mathrm{cC}$ & $0.20 \mathrm{aB}$ & $0.14 \mathrm{aD}$ & $0.27 \mathrm{bB}$ & $0.65 \mathrm{aA}$ & $0.53 \mathrm{bD}$ \\
210 & $0.23 \mathrm{bB}$ & $0.21 \mathrm{aB}$ & $0.17 \mathrm{aD}$ & $0.31 \mathrm{aA}$ & $0.60 \mathrm{bB}$ & $0.48 \mathrm{cE}$ \\
\hline
\end{tabular}

Young leaves modified on new light conditions, increasing the number of leaflets when transferred to sun (Fig. 5) and, producing a sun plants structure. Mature leaves consisted of 15-25 leaflets in sun plants, while in shade plants the average was 5-10.

When plants were transferred from sun to shade, defoliation was not marked and the modification of plants occurred in new leaves by decreasing the leaf number, number of leaflets per leaf (Fig. 5) and Pn (Fig. 4D).

\section{DISCUSSION}

The light conditions for $C$. fissilis were similar to those measured in Santa Genebra forest, Campinas district, Brazil, where R:FR ratio of 0.4-0.74 was observed, and attained 1.22-1.44 in open area (Souza and Valio, 1999). Growth of the tropical shrub Psychotria aubletiana (Rubiaceae) is affected by habitat (Amézquita, 1998). In gaps and borders of forest the relative growth of this species is higher than that one under the canopy. $C$. odorata, was considered as a species dependent on light in rain forests, and the gaps positively 
influenced its growth only during the wet season (Gerhardt, 1996).

The stem elongation of 30-days-old seedlings (Fig. 1A) and low dry mass of shade C. fissilis hypocotyls (Table 2) indicated a typical photomorphogenetic response to low R:FR ratio, where probably only cell elongation occurred without cell division. Kitagima (1994) noted the same response in Ochroma, Ceiba and Pseudobombax, and gave the conclusion that it was the unique response to low R:FR ratio in the low canopy level. The modification in elongation response of $C$. fissilis sun plants showed the similarities with $C$. odorata, whose seedlings in canopy gaps were taller than under the forest canopy (Poorter and Hayahida-Oliver, 2000). In a study of effect of the light environment on young plants of C. odorata, Diosporus digyna and Pouteria sapota in primary and secondary forest and pasture (Ricker et al., 2000), C. odorata grow fastest in gaps, and the highest growth occurred when they were in gaps of up to $78 \%$ of canopy openness, confirming the light dependence for growth of the species. In advanced growth, stem elongation of $C$. fissilis (Fig. 1A) was limited by light resource availability (Table 1).

Faster growth in stem diameter of sun comparing to shade plants (Fig. 1B) produced more vigorous plants. The stem diameter of Croton urucurana (pioneer species), Peltophorum dubium, Lonchocarpus muehlbergianus (early secondary species), Tabebuia impetiginosa and Genipa americana (climax species) was higher under full sun and under $40 \%$ of artificial shade, than in natural shade (Moraes Neto et al., 2000). In the same experiment, the height of pioneer species was similar under both light treatments; secondary species and Tabebuia impetiginosa (climax) elongated the stem better under full sun and at $40 \%$ shade.

The number of leaves and leaflets under full sun was, on average, twice that of shade plants (Fig. 1C). Some other tropical species showed the similar response, as in C. odorata, which increased twice the number of leaves growing in gaps when compared to shade grown plants (Pooter and Hayahida-Oliver, 2000). The leaf area in shade plants was restricted up to ten times in young plants of C. fissilis (Fig. 4B), that was common to many others species of tropical forests, as Psychotria aubletiana (Amérzquita, 1998), and for species differing in successional status (Souza and Válio, 2003).
The underground growth of $C$. fissilis measured by root development and root mass evolution (Fig. 1D and Table 2) occurred in the similar trend as in C. odorata (Poorter and Hayahida-Oliver, 2000). The higher length of root occurred in sun grown plants suggesting that it explored a larger area and depth of soil for humidity and nutrients, guaranteeing its possible survival during dry season compared to the less developed root system under shade.

The RGR of $C$. fissilis (0.011-0.48) stayed in the interval of RGR determined for tropical species (0.03-0.089) reported by Paulilo et al. (1993). C. fissilis showed increasing RGR values between $90^{\text {th }}$ and $150^{\text {th }}$ days (Fig. 2A). Similar effect of latter reduction of RGR was noted in young plants of Cedrelinga catenaeformis, where RGR was even reduced in all light treatments $(0,30,50$ and $70 \%$ shading) during an initial period of $30-90$ days. Thereafter during 90-120 days, RGR increased specially in plants grown under the 50 and $70 \%$ of shading (Farias et al., 1997).

The pioneer species (Cecropia pachystachya and Schizolobium parahyba) invested the carbon preferentially in aerial growth than in roots under sun, while the shade tolerant species (Myroxylon peruiferum and Hymenaea courbaril) reduced proportionally the investment in aerial growth, investing more in other compartments, for their maintenance under the shade (Souza and Valio, 1999). Considering that the shade plants of $C$. fissilis after 150 days showed practically zero growth (Fig. 2B) and that the carbon is invested preferentially in leaves, the growth analyses lead to its classification as relative shade intolerance characteristics. Also, shade tolerant species allocate more resources for leaf production, with higher LMR and RAP and relatively low root mass (Agyeman et al., 1999). This is the phenotypic response of species adapted to shade (Kitagima, 1994), due to the increased photosynthetic rate in relation to respiration on whole plant level, contributing to maintenance of positive carbon balance and maximizing growth under shade.

The NAR determines the total plant growth, and it is coherent with estimations of energy system conservation in secondary forests (Ackerly, 1996). Therefore, LMA always increases to compensate the low radiation level, and RGR is less sensitive than NAR to reduction in radiation. NAR and RGR were lower under shade in C. fissilis, performance that generally characterized shade plants (Souza and Válio, 2003). 
Under shade conditions, $C$. fissilis showed positive net photosynthesis even under a radiation level equal to light compensation point of the majority of plants, showing a strategy of shade adapted species (Pastenes et al., 2003). Plants grown in forest and exposed to sun radiation inside greenhouse and under midday sun, showed a restricted Pn compared to sun plants (Fig. 4A) probably due to the photoinhibition in order of few hours (Karim et al., 2003). On the other hand, leaves of $C$. fissilis sunny plants had the ability to respond to strong light.

Low photosynthetic rate of $C$. fissilis shade seedlings (Fig. 4A), which maintained the slow developed plant leaf structure (Fig. 4B), reduced RAP (Table 3) and RAP (Fig. 3A), indicate that they allocated relatively more of biomass to aerial part than to roots. Generally, plants under the shade invest more in leaves, to optimize light interception (Kasperbauer and Karlen, 1994). The paradigm of optimization has faced severe criticism, due to its tendency to isolate one individual character of an organism integrated to light environment (Valladares and Pearcy, 2000). Investment in leaves for better light interception competes with a water uptake function (Rajcan and Swanton, 2001). Usually, leaves developed under reduced light quantity, present higher total Chl content than leaves under full sun (Ribaski, 2000). This outcome appears because $\mathrm{Chl}$ is constantly synthesized and decomposed under light. When submitted to a high light flux the rate of decomposition still is higher (Kramer and Kozlowski, 1979). In C. fissilis, where similar content of Chl was observed in sun and shade plants (Fig. 4D), the Chl content did not change under modified light microclimatic conditions in adaptation of photosynthetic apparatus from sun to shade, (Fig. 4D), for the maintenance of Pn (Fig. 4B) above the light compensation point. Moreover, when of sun plants were shaded, the content of $\mathrm{Chl} \mathrm{b}$ increased and the $\mathrm{Chl} \mathrm{a}: \mathrm{b}$ ratio decreased (Fig. 4D), but no significant difference was detected under tested conditions (Fig. 4D). Concentration of pigments calculated on a fresh weight basis in mahogany and Coumarouna odorata leaves, was highest in shade grown plants, but when calculated on a leaf area basis were similar (Gonçalves et al., 2001) in trees grown under shade and full sun as reported here in $C$. fissilis.

The acclimation of two shrub species tolerant to shade, with a life span of 2 and 5 years, (Kursar and Coley, 1999) was different. Both species showed photoinhibition, when shade leaves were transferred to full sun. After 17 days the species with the shorter leaf life span (Hybanthus prunifolius) lost all leaves. This species has the high degree of plasticity, compensating the initial drop in leaf area by increase in the photosynthetic rate. The plants were well developed, with new structure, after three months under sunlight. $C$. fissilis showed a similar tendency in morphological and physiological responses. Considering that the adaptation occurs on still developed modules and on those to be developed (Strauss-Debendetti and Bazzaz, 1991), the physiological plasticity of $C$. fissilis leaves could increase its morphological and physiological adaptation in canopy gaps (Fig. 5).

Cedrela fissilis is a species with the capacity for adaptation to different light conditions. It germinates under both light and shade conditions, but grows very slowly under shade, waiting for the opening of gaps in forest canopy to increase the rate of development. The physiological plasticity of $C$. fissilis is less conservative than its morphological plasticity, considering the fast adaptation of gas exchange to relatively rapid change in radiation (one day scale). On the other hand, plants transferred from shade to sun, lost all their old leaves during a 15 day-period, not preserving the previous morphology, but adapting young leaves to the new conditions, both in morphology and in net photosynthesis rate. When transferred to shade, sun plants did not lose the leaves. But they did not attain the photosynthetic response of plants maintained in shade, which explained the preservation of a large leaf area to compensate the low Pn. Inoue (1980) reported that C. fissilis presented the ability to acclimatize to light and that at high temperature, high light irradiance was necessary for maximum productivity and although $C$. fissilis was able to adapt to different light conditions, it showed an umbrophilous character.

Our results show that $C$. fissilis grown at different light conditions has the ability of physiological adaptation in the short-term scale run, and changes its morphology in the long run.

\section{RESUMO}

Cedrela fissilis foi semeada e mantida em dois ambientes de luz: na margem leste (tratamento sol 
- razão vermelho: vermelho extremo da radiação solar direta foi 1,15) e sob dossel de floresta (tratamento sombra - radiação fotossinteticamente ativa reduzida de 0.22 a $7 \%$ da radiação direta e razão vermelho:vermelho extremo de 0,21 a 0,36 ). $\mathrm{O}$ crescimento em altura e diâmetro do caule no sol foi mais rápido, o desenvolvimento do sistema radicular continua, o número de folhas foi em média o dobro das de sombra, quanto à área foliar foi 10 vezes maior em plantas de sol com 15-25 folíolos por folha, enquanto as plantas da sombra desenvolveram de 5 a 10. Nas plantas de sombra, as maiores proporções de matéria seca foram investidas em parte aérea. A capacidade de troca de gases das plantas da sombra expostas na radiação alta não aumentou. Quando plantas de sombra foram transferidas ao sol e mantidas por 15 dias, apenas as folhas jovens se adaptaram às condições de radiação aumentada, atingindo a capacidade de resposta das folhas das plantas de sol, enquanto as folhas mais velhas caíram. As plantas de sol transferidas para a sombra não perderam as folhas, mas não atingiram a resposta das plantas de sombra.

\section{ACKNOWLEDGEMENTS}

This work was supported by grants from CNPq, FAPESP, FUNDUNESP and IICA. We thank to Viveka Kudaligama and Eduardo C. Miranda for English review. MT is grateful to $\mathrm{CNPq}$ for research fellowship.

\section{REFERENCES}

Ackerly, D. D. (1996), Canopy Structure and Dynamics: Integration of Growth Processes in Tropical Pioneer Trees, In: Mulkey, S. S.; Chazdon, R. L. and Smith, A. P. (Eds.). Tropical forest plant ecophysiology. New York: Chapman and Hall. pp. 619-53.

Agyeman, I. B.; Swaine, M. D. and Thompson, J. (1999), Responses of tropical forest tree seedlings to irradiance and derivation of light response index. Journal of Ecology, 87, 815-27.

Amézquita, P. (1998), Light environment affects seedling performance in Psychotria aubletiana (Rubiaceae), a tropical understory shrub. Biotropica, 30, 126-9.
Aphalo, P. J.; Ballare, C. L. and Scopel, A. L. (1999), Plant - plant signaling, the shade avoidance response and competition. Journal of Experimental Botany, 340, 1629-1634.

Arnon, D. I. (1949), Copper enzymes in isolated chloroplast polyphenoloxidases in Beta vulgaris. Plant Physiology, 24, 1-15.

Ballaré, C. L. and Casal, J. J. (2000), Light signals perceived by crop and weed plants. Field Crops Research, 67, 149-160.

Carvalho, P. E. R. (1994), Espécies Florestais Brasileiras: Recomendações Silviculturais, Potencialidades e uso da madeira. Colombo, PR: EMBRAPA, CNPF.

Casal J. J. and Sánchez R. A. (1998), Phytochromes and seed germination. Seed Science Research, 8, 317-329.

Farias, C. C. V.; Varela, P. V.; Costa, S. S. and Batalha, P. V. L. (1997), Análise do crescimento de mudas de cedrorana (Cedrelinga catenaeformis (Ducke) cultivadas em condições de viveiro. Revista Brasileira de Sementes, 19,193-200.

Gautier, H.; Mech, P.; Prusinkiewicz, P. and VarletGrancher, C. (2000), 3D Architectural modeling of aerial photomorphogenesis in White Clover (Trifolium repens L.) using L-systems. Annals of Botany, 85, 359-370.

Gerhardt, K. (1996), Effects of root competition and canopy openness on survival and growth of tree seedlings in a tropical seasonal dry forest. Forest Ecology and Management, 82, 33-48.

Givnish, T. J. (1988), Adaptation to sun and shade: a whole-plant perspective. Australian Journal of Plant Physiology, 15, 63-92.

Gonçalves, G. F. C.; Marenco, R. A. and Vieira, G. (2001), Concentration of photosynthetic pigments and chlorophyll fluorescence of mahogany and tonka bean under two light environments. Revista Brasileira de Fisiologia Vegetal, 13, 149-157.

Héraut-Bron, V.; Robin, C.; Varlet-Grancher, C. and Guckert, A. (2001), Phytochrome mediated effects on leaves of white clover: consequences for light interception by the plant under competition for light. Annals of Botany, 88, 737-743.

Hunt, R. (1982), Plant growth curves. The functional approach to plant growth analysis. London: Edward Arnold.

Inoue, M. T. (1980), Photosynthesis and transpiration in Cedrela fissilis Vell. seedlings in relation to light intensity and temperature. Turrialba, 30, 280-283.

Karim, A.; Fukamachi, H and Hidaka, T. (2003), Photosynthetic performance of Vigna radiata $\mathrm{L}$. leaves developed at different temperature and irradiance levels. Plant Science, 164, 451-458.

Kasperbauer, J. M. and Karlen, L. D. (1994), Plant spacing and reflected far-red light effects on phytochrome-regulated photosynthate allocation in corn seedlings. Crop Science, 34, 1564-1569. 
Kitagima, K. (1994), Relative importance of photosynthetic traits and allocation patterns as correlates of seedlings shade tolerance of 13 tropical trees. Oecologia, 98, 419-28.

Kramer, P. J. and Kozlowski, T. T. (1979) Physiology of woody plants. New York: Academic Press.

Kull, O. and Kruijt, B. (1998), Leaf photosynthetic light response: a mechanistic model for scaling photosynthesis to leaves and canopies. Functional Ecology, 12, 767-777.

Kursar, T. A. and Coley, P. D. (1999), Contrasting modes of light acclimation in two species of the rainforest undrestory. Oecologia, 121, 489-498.

Leopold, A. C. and Kriedemann, P. E. (1978), Plant growth and development. $2^{\text {nd }}$ ed. New Delhi: Tata MacGraw-Hill.

Marquis, R. J.; Young, H. J. and Braquer, H. E. (1994), The influence of understorey vegetation cover on germination and seedling establishment in tropical low land wet forest. Biotropica, 18, 273-278.

Moraes-Neto, P. S.; Gonçalves, M. L. J.; Takaki, M.; Cenci, S. and Gonçalves, C. J. (2000), Crescimento de mudas de algumas espécies arbóreas que ocorrem na mata atlântica, em função do nível de luminosidade. Revista Árvore, 24, 35-45.

Pastenes, C.; Santa-María E.; Infante R. and Franck, N. (2003), Domestication of the Chilean guava (Ugni molinae Turcz.), a forest understorey shrub, must consider light intensity, Scientia Horticulturae, 98, 71-84.

Paulilo, T. M.; Felippe, G. M. and Dale, E. J. (1993), Crescimento inicial de Qualea grandiflora. Revista. Brasileira de Botânica, 16, 37-46.

Planchais, I. and Sinoquet, H. (1998), Foliage determinants of light interception in sunny and shaded branches of Fagus silvatica (L.). Agricultural and Forest Meteorology, 89, 241-253.

Pooter, H. and Hayashida-Oliver, Y. (2000), Effects of seasonal drought on gap and understory seedlings in a Bolivian moist forest. Journal of Tropical Ecology, 16, 481-98.

Rajcan, I. and Swanton, C. J. (2001), Understanding maize-weed competition: resource competition, light quality and whole plant. Field Crops Research, 71, 139-150.

Rakocevic, M. (1997), Photomorphogenetic responses in plant species of upland grasslands in Serbia. Review of Research Work at the Faculty of Agriculture, Belgrade, 42, 111-125.

Ribaski, J. (2000), Influência da algaroba (Prosopis juliflora (SW) DC) sobre a disponibilidade e qualidade da forragem de capim-búfel (Cenchrus ciliaris) na região semi-árida brasileira. $\mathrm{PhD}$ Thesis. UFPR, Curitiba, Brazil.
Richardson, A. D.; Ashton, P. M. S.; Berlyn, G. P.; McGroddy, M. E. and Cameron, R. I. (2001), WithIn: crown foliar plasticity of Western Hemlock, Tsuga heterophylla, in relation to stand age. Annals of Botany, 88, 1007-1015.

Ricker, M.; Siebe, C.; Sanchez, B. S.; Shimada, K.; Larson, C. B.; Martini-Ramos, M. and Montagnini, F. (2000), Optimizing seedling management: Pouteria sapota, Diospyros digyna and Cedrela odorata in a Mexican rainforest. Forest Ecology and Management, 139, 63-77.

Smith, H. (1994), Sensing the light environment: the functions of the phytochrome family. In: Kendrick, R. E. and Kronenberg, H. H. M. (Eds.). Photomorphogenesis in plants. Dordrecht: Kluwer Academic Publishers. pp. 377-416.

Souza, R. P. and Válio, I. F. M. (1999), Carbon translocation as affected by shade in saplings of shade tolerant and intolerant species. Biologia Plantarum, 42, 631-36.

Souza, R. P. and Válio, I. F. M. (2003), Seedling growth of fifteen Brazilian tropical tree species differing in succescional status. Revista brasileira de Botânica, 26, 35-47.

Strauss-Debenedetti, S. and Bazzaz, F. A. (1991), Plasticity and acclimation to light in tropical Moraceae of different successional positions. Oecologia, 87, 377-387.

Valladares, F. and Pearcy, R. W. (2000), The role of crown architecture for light harvesting and carbon gain in extreme light environments assessed with a realistic 3-D model. Anales Jadin Botanico De Madrid, 58, 3-16.

Vazques-Yanes, C. and Smith, H. (1982), Phytochrome control of seed germination in tropical rain forest pioneer trees Cecropia obtusifolia and Piper auritum and its ecological significance. The New Phytologist, 92, 477-485.

Walters, M. B. and Reich, P. B. (1996), Are shade tolerance, survival and growth linked? Low light and effects on hardwood seedlings. Ecology, 77, 841-53.

Wareing, P. F. and Phillips, I. D. J. (1970), The control of growth and differentiation in plants. Oxford: Pergamon.
Received: May 25, 2004; Revised: November 12, 2004; Accepted: August 05, 2005. 